\title{
Cryopreservation of Prochilodus brevis semen: freezing media and thawing rates
}

\section{Título em PortuguêsCriopreservação do sêmen de Prochilodus brevis: meios de congelação e taxas de descongelação}

\author{
Larissa Teixeira Nunes ${ }^{1}$; Mayara Setúbal Oliveira ${ }^{1}$; Júlia Trugilio Lopes ${ }^{1}$; \\ Maria Eduarda Magalhães de Souza'; Romulo Roberto Ribeiro Pinheiro3; \\ Cláudio Cabral Campello ${ }^{4}$; Carminda Sandra Brito Salmito Vanderley ${ }^{5 *}$
}

\begin{abstract}
Prochilodus brevis is a migratory fish, an important component of its river ecosystem and an appreciated animal in northeastern cuisine. However, human activities have threatened its survival. Thus, researchers have become interested in developing genetic material storage protocols, such as seminal cryopreservation. Therefore, determination of the appropriate freezing media and thawing rate is a fundamental step toward the use of this biotechnology in the production of common curimatã and for reducing risks to the species' survival. As such, the aim of the current study was to evaluate the effect of different freezing media and thawing rates on the quality of cryopreserved semen from P. brevis. For this study, males received a single dose of pituitary extract of carp 18 hours before semen collection. The semen samples were diluted in $5 \%$ glucose $+10 \%$ methyl glycol (MG), $5 \%$ glucose $+10 \%$ dimethyl sulfoxide (DMSO), $0.9 \% \mathrm{NaCl}+$ $10 \%$ methyl glycol, and $0.9 \% \mathrm{NaCl}+10 \%$ dimethyl sulfoxide, loaded into $0.25-\mathrm{mL}$ straws and frozen in liquid nitrogen vapor. The semen from each treatment was thawed at three different thawing rates: 25 ${ }^{\circ} \mathrm{C}$ for $30 \mathrm{sec}, 30{ }^{\circ} \mathrm{C}$ for $16 \mathrm{sec}$ and $40{ }^{\circ} \mathrm{C}$ for $12 \mathrm{sec}$. Motility, vitality and morphology analyses were performed by computer-assisted sperm analysis (CASA). The characteristics of the fresh sperm mostly resembled those found in the literature. For the parameters analyzed, fresh sperm presented higher sperm quality in comparison to all treatments with cryopreserved sperm $(\mathrm{p}<0.05)$, except for the characteristic of normal morphology, for which the sperm cryopreserved in glucose and MG did not differ statistically from the fresh sperm. For the cryopreserved semen, the greatest results of total motility and curvilinear velocity (VCL) were obtained using glucose and DMSO, regardless of the thawing rate employed. For the straight-line velocity (VSL) and average path velocity (VAP), DMSO showed the best results, regardless of the diluent and thawing rate. With regard to vitality, the highest values were achieved when DMSO and thawing rates of $30^{\circ} \mathrm{C}$ for $16 \mathrm{sec}$ or $40^{\circ} \mathrm{C}$ for $12 \mathrm{sec}$ were used. In the morphological analysis, the greatest percentage of normal sperm cells was obtained using thawing rates of $25^{\circ} \mathrm{C}$ for $30 \mathrm{sec}$ and $40^{\circ} \mathrm{C}$ for $12 \mathrm{sec}$, regardless of the freezing media. Sperm quality was found to suffer interference from the freezing media, as well as from interaction between its components (diluent and cryoprotectant) and the thawing rate used. Under the methodological conditions employed, the use of 5\% glucose $+10 \%$ DMSO and a thawing rate of $30{ }^{\circ} \mathrm{C}$ for 16 seconds or $40{ }^{\circ} \mathrm{C}$ for 12 seconds is recommended for P. brevis semen cryopreservation.

Key words: Cryoprotective agent. Curimatã comum. Sperm extender. Sperm freezing. Sperm quality. Thawing temperature.
\end{abstract}

\footnotetext{
${ }^{1}$ Discentes do Curso de Doutorado, do Programa de Pós-Graduação em Ciências Veterinárias da Universidade Estadual do Ceará, UECE, Fortaleza, CE, Brasil. E-mail: larissatn.br@hotmail.com; mayara_setubal@hotmail.com; juliatrugilio@gmail.com

2 Discente do Curso de Graduação em Medicina Veterinária, UECE, Fortaleza, CE, Brasil. E-mail: eduardadesouza@hotmail.com

${ }^{3}$ Discente do Curso de Graduação em Ciências Biológicas, UECE, Fortaleza, CE, Brasil. E-mail: romuloroberto_bio@hotmail.com

${ }^{4}$ Prof. Dr., Faculdade de Veterinária, UECE, UECE, Fortaleza, CE, Brasil. E-mail: claudio.campello@uece.br

5 Prof $^{a}$ Dr $^{\text {a }}$ do Curso de Ciências Biológicas, UECE, Fortaleza, CE, Brasil. E-mail: sandra.salmito@uece.br

* Author for correspondence
} 


\section{Resumo}

O Prochilodus brevis é um peixe reofílico, importante componente do ecossistema fluvial e apreciado na culinária nordestina. No entanto, ações antrópicas têm ameaçado sua sobrevivência. Desta forma, surge, nos pesquisadores, o interesse no desenvolvimento de protocolos de conservação do material genético, como a criopreservação seminal. Logo, a determinação do meio de congelação e da taxa de descongelação adequados, são passos fundamentais que possibilitarão a utilização dessa biotecnologia na produção de curimatã comum, reduzindo os riscos à sua sobrevivência. Portanto, o objetivo desse trabalho foi avaliar o efeito de diferentes meios de congelação e taxas de descongelação sobre a qualidade do sêmen criopreservado de P. brevis. Para isso, 18 horas antes da coleta de sêmen, os machos receberam dose única de extrato hipofisário de carpa. Cada animal foi sedado com solução à base de eugenol e o sêmen foi coletado. As amostras foram diluídas em quatro meios de congelação (5\% Glicose + Metilglicol 10\%; $5 \%$ Glicose + DMSO 10\%; 0,9\% NaCl + Metilglicol 10\%; 0,9\% NaCl + DMSO 10\%) envasadas em palhetas de $0,25 \mathrm{~mL}$ e congeladas em vapor de nitrogênio líquido. O sêmen foi descongelado após sete

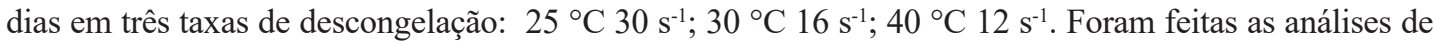
motilidade, vitalidade e morfologia com auxílio de sistema automatizado de análise seminal (CASA). As características do sêmen in natura assemelharam-se, em sua maioria, às encontradas na literatura. Para os parâmetros analisados, o sêmen in natura apresentou qualidade seminal superior a todos os tratamentos com o sêmen criopreservado $(\mathrm{p}<0,05)$, exceto para a morfologia normal, no sêmen criopreservado em Glicose e MG, que não diferiu estatisticamente do sêmen in natura ( $>00,05)$. Para o sêmen criopreservado, os maiores índices foram alcançados quando se utilizou DMSO e as taxas de descongelação de $30^{\circ} \mathrm{C} 16 \mathrm{~s}^{-1}$

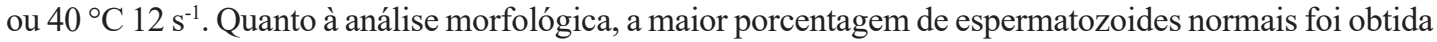

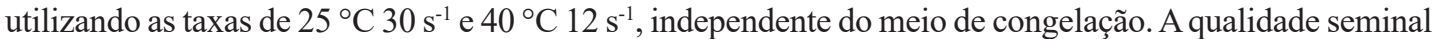
sofre interferência do meio de congelação, bem como da interação entre seus componentes (diluente e crioprotetor) e da taxa de descongelação empregada. Sob as condições metodológicas empregadas, recomenda-se a criopreservação do sêmen de $P$. brevis em 5\% Glicose + DMSO 10\% e descongelação a $30{ }^{\circ} \mathrm{C}$ durante 16 segundos ou $40{ }^{\circ} \mathrm{C}$ durante 12 segundos.

Palavras-chave: Agente crioprotetor. Curimatã comum. Diluente espermático. Congelação de sêmen. Qualidade espermática. Temperatura de descongelação

\section{Introduction}

Prochilodus brevis or, as it is known regionally, the common curimatã is a migratory fish that belongs to the order Characiformes. It is endemic in the states of Piauí, Ceará and Rio Grande do Norte but is currently distributed in the Northeast and part of the Southeast. Its ecological importance is related to its scavenger diet as an adult (DOURADO, 1981). This feature is critical to the river ecosystem because waste is the primary pathway of energy and material flow in most ecosystems, supporting higher trophic levels and providing a major source of regeneration and absorption of inorganic nutrients. Therefore, the loss of scavenging species could disrupt the functioning of an ecosystem (MOORE et al., 2004). Another important aspect is the social importance of the species because its consumption is more related to subsistence, although it has a strong economic appeal in some regions.

Hydroelectric dam construction, overfishing, lack of rain and pollution are some factors that have affected the migration of species and have therefore altered river dynamics, threatening the survival of several species of fish, particularly rheophilics such as $P$. brevis. Therefore, the development of biotechnologies for the aquaculture of this species is necessary to conserve it in wild stocks and commercial production. Few studies are available on assisted reproduction of $P$. brevis; as such, researchers have become interested in obtaining information to support the development of genetic material conservation protocols.

In this context, interest in semen cryopreservation is growing for the reproduction of species possessing 
characteristics of interest and that are threatened (RESENDE; MARQUES, 2009). However, specific cryopreservation protocols must be determined for each species.

During the cryopreservation process, injuries to sperm cells should be avoided because good fertilization rates are the result of preserving the normal functions of these gametes. The steps of this process must be adapted to the particularities of each species (CARNEIRO et al., 2012). Thus, knowing the freezing media that interact best with the spermatozoa of the common curimatã is essential to prevent damage and to provide essential nutrients to the gametes.

Another key issue in successful cryopreservation is the use of appropriate temperature and time during thawing because this is one of the critical moments of cell stress (LEUNG, 1991). During this process, the cells not only need time to rehydrate but also must thaw quickly enough to avoid the formation of ice crystals that may become large enough to break the membrane and cause cell death (RESENDE; MARQUES, 2009). The use of an optimal thaw rate decreases the stress caused to sperm, keeping them viable for fertilization.

Therefore, the development of an effective protocol for cryopreservation of the semen of $P$. brevis may lead to better post-thaw sperm quality, allowing an increase in the reproduction of this species in captivity, thereby meeting the demand for this fish and preventing the depletion of its natural stocks. Thus, this study aimed to evaluate the effects of different media for freezing and of thawing rates on the kinetics, morphology and vitality of cryopreserved sperm of $P$. brevis.

\section{Materials and Methods}

\section{Handling of animals and semen collection}

The project was approved by the Ethics Committee for the Use of Animals of the State
University of Ceará (5385787/2014). The experiment was carried out between January and April 2014 in the Laboratory of Biotechnology Fish Reproduction - LBRP (3॰47'36.2”S; $\left.38^{\circ} 33^{\prime} 30.1^{\prime \prime} \mathrm{W}\right)$, located at the State University of Ceará, Itaperi Campus, Fortaleza, Ceará, Brazil.

The $P$. brevis specimens used in this study were kept in 7100 L fiberglass tanks with constant aeration. The animals were fed twice a day with commercial feed ( $32 \%$ crude protein) at a proportion of $3 \%$ of animal biomass. Twentynine specimens, whose weight and average length were $118.00 \pm 22.38 \mathrm{~g}$ and $19.72 \pm 1.01 \mathrm{~cm}$, respectively, were used in the study. Animals that had hyperemic urogenital papilla and released a detectable amount of semen under mild abdominal pressure were injected intracelomically with one dose ( $3 \mathrm{mg} \mathrm{kg}^{-1}$ body weight) of pituitary extract of carp (CPE). Eighteen hours after hormonal induction, each animal was removed from the tank, where they had been maintained in water with an average temperature of $27^{\circ} \mathrm{C}$, totaling 486 hours-degree, and were sedated with a clove oil-based solution (Eugenol; União Vegetal Suplementos Nutricionais Ltda) in a ratio of 1:10:10,000 (eugenol: alcohol: water). Then, a paper towel was used to dry the animal's urogenital papilla completely to avoid contamination, and the eyes were wrapped in a damp cloth to facilitate constraint and to minimize stress. A slight abdominal pressure was performed from head to tail to obtain release of the semen, which was collected and stored in graduated tubes of polyethylene and kept in an insulated box with ice at approximately $4{ }^{\circ} \mathrm{C}$ until processing of the samples, but not exceeding 30 minutes.

For the experiment, samples $(n=20)$ that met the following criteria were selected: no previous activation (attributed to contamination by water, urine, feces or blood), motility greater than $85 \%$ after activation with $50 \mathrm{mM} \mathrm{NaCl}$ and sufficient volume for cryopreservation. 


\section{Evaluation of fresh sperm}

Initially, semen volume (mL) was measured using graduated tubes. Then, semen aliquots of each animal were taken for an analysis of seminal $\mathrm{pH}$ and osmolarity; and sperm concentration, kinetics, vitality and morphology.

The osmolarity and $\mathrm{pH}$ were measured with a digital Peltier cooling osmometer (Roebling, Germany) and $\mathrm{pH}$ strips (Merck, Germany), respectively.

Sperm concentration was estimated by counting the cells using a Neubauer chamber on an optical microscope aid (400x), with a sperm drop of $2 \mu \mathrm{L}$ from each animal diluted in formol-citrate solution 4\% (2.9 g sodium citrate, $4 \mathrm{~mL}$ commercial solution of $37 \%$ formaldehyde and distilled water q.s. 100 $\mathrm{mL}$ ) at a rate of 1:4000 (semen: fixing solution).

Kinetics were evaluated by computer-assisted sperm analysis (CASA) with Sperm Class Analyzer software (SCA Microptics - Barcelona - Spain, version 3.2) after homogenization of $1 \mu \mathrm{L}$ semen with $100 \mu \mathrm{L}$ of activator solution $(50 \mathrm{mM} \mathrm{NaCl}$ $100 \mathrm{mOsm})$. The parameters evaluated were total motility, curvilinear velocity (VCL), straight-line velocity (VSL) and average path velocity (VAP). At least 2000 spermatozoa for were assessed in the analysis.

For vitality, smears were prepared (one slide/ animal) after staining of the sperm with the eosinnigrosine method (adapted from BLOM, 1950) using the ratio 1:10:10 (semen: eosin: nigrosine). The reading of smears (200 sperm per animal) was performed using the SCA program in the "Counter" module. The spermatozoa were considered alive if they appeared to be colorless (indicating intact cytoplasmic membrane) and dead if appearing pink or red (indicating a break in the cytoplasmic membrane).

The morphological analysis occurred after semen had been fixed in the formol-citrate solution $4 \%$ in a ratio of 1:100 (semen: fixing solution) and subsequently stained with Rose Bengal in a ratio of 1:2 (dye: fixed semen) according to the methodology established by Torres et al. (2013). Two slides were prepared per animal and 100 spermatozoa per slide were evaluated according to the classification proposed by Miliorini et al. (2011). Readings were taken in the SCA program using the "Counter" module.

\section{Sperm cryopreservation and thawing}

One sperm aliquot from each animal was diluted in four different freezing media that were composed by the association of two diluents (5\% Glucose or $0.9 \% \mathrm{NaCl})$ with two cryoprotectants $(10 \%$ dimethyl sulfoxide - DMSO or $10 \%$ methyl glycol - MG). The diluted sperm was loaded into $0.25 \mathrm{~mL}$ French straws (5 replicates), sealed with polyvinyl alcohol and kept refrigerated $\left(\sim 4^{\circ} \mathrm{C}\right)$ for 10 minutes to allow the samples time to reach equilibrium. Thereupon, the straws were frozen in a dry shipper for 15 minutes and transferred to a liquid nitrogen container at $-196{ }^{\circ} \mathrm{C}$. A total of 400 straws were cryopreserved (5 replicates x 4 treatments $\times 20$ animals).

After 15 days, the samples were thawed in a water bath using three thawing rates: $25^{\circ} \mathrm{C}$ for 30 seconds, $30{ }^{\circ} \mathrm{C}$ for 16 seconds and $40{ }^{\circ} \mathrm{C}$ for 12 seconds. The post-thawed sperm was subjected to motility, morphology and vitality analysis, following the same methodology used for the fresh sperm, which was used as a control.

\section{Statistical analysis}

The data were subjected to Shapiro-Wilk and Bartlett tests to verify the normal distribution of waste and homoscedasticity, respectively. After both of these requirements had been confirmed, the analysis of variance (ANOVA) was performed using the PROC GLM of SAS program, 2002, considering a completely randomized design in a factorial $2 \times 2 \times 3$, represented by the effect of the 
cryoprotectants (dimethyl sulfoxide and methyl glycol), the diluent effect (glucose and $\mathrm{NaCl}$ ), the effect of thawing $\left(25^{\circ} \mathrm{C}\right.$ for $30 \mathrm{sec}, 30^{\circ} \mathrm{C}$ for $16 \mathrm{sec}$ and $40{ }^{\circ} \mathrm{C}$ for $12 \mathrm{sec}$ ) and the interactions between the main effects. When some significant difference was observed in a main effect or interaction, comparisons between the treatments were made using the Student-Newman-Keuls test. The results were presented as the mean \pm standard error. Differences were considered significant at $\mathrm{p}<0.05$.

\section{Results and Discussion}

\section{Evaluation of fresh sperm}

The results of the characterization of the fresh sperm and the weights and lengths of the individual P. brevis $(\mathrm{n}=20)$ are described in Table 1 .

Table 1. Body weight and length and fresh sperm characteristics of the common curimatã, mean \pm standard deviation.

\begin{tabular}{|c|c|c|}
\hline Characteristics & Mean & $\mathrm{SD}$ \\
\hline Body weight (g) & 118 & 22.38 \\
\hline Length $(\mathrm{cm})$ & 19.72 & 1.01 \\
\hline Volume (mL) & 0.56 & 0.24 \\
\hline $\mathrm{pH}$ & 8.50 & 0.21 \\
\hline Osmolarity $\left(\mathrm{mOsm} \mathrm{kg}^{-1}\right)^{*}$ & 287.50 & 26.51 \\
\hline Concentration (sptz x $10^{9} \mathrm{~mL}^{-1}$ ) & 27.89 & 6.13 \\
\hline Spermatozoa with intact membranes & 96.76 & 1.46 \\
\hline Spermatozoa with normal morphology & 74.18 & 10.63 \\
\hline Total motility $(\%)^{* *}$ & 99.02 & 3.20 \\
\hline $\operatorname{VCL}\left(\mu \mathrm{m} \mathrm{s}^{-1}\right)^{* *}$ & 144.50 & 32.56 \\
\hline $\operatorname{VSL}\left(\mu \mathrm{m} \mathrm{s}^{-1}\right)^{* *}$ & 48.30 & 8.02 \\
\hline $\operatorname{VAP}\left(\mu \mathrm{m} \mathrm{s}^{-1}\right) * *$ & 101.70 & 19.32 \\
\hline
\end{tabular}

$*_{\mathrm{n}}=4 ; * *_{\mathrm{n}}=15 . \mathrm{VCL}=$ Curvilinear velocity; $\mathrm{VSL}=$ straight-line velocity; VAP $=$ Average path velocity.

\section{Sperm cryopreservation and thawing}

For the analyzed parameters, the fresh sperm presented higher spermatic quality than all treatments with cryopreserved sperm $(\mathrm{p}<0.05)$, except for the normal morphology in sperm cryopreserved in glucose and $\mathrm{MG}$, which was not significantly different from that of the fresh sperm $(\mathrm{p}>0.05)$.
With regard to total motility, the cryoprotectant and extender factors had a significant effect (Figure 1). DMSO gave the highest rate, $32.87 \pm$ $1.21 \%$, regardless of the extender and thawing rate used when compared to $\mathrm{MG}$, which had a rate of $16.06 \pm 1.58 \%(p<0.05)$. Glucose also had the highest percentage of total motility, $27.04 \pm 1.84 \%$, regardless of the cryoprotectant and thawing rate employed, compared to $\mathrm{NaCl}$, which had a motility of $21.94 \pm 1.27 \%(\mathrm{p}<0.05)$. 
Figure 1. The mean \pm standard error of total motility of sperm from the common curimatã, cryopreserved in different freezing media. A) Lowercase letters indicate a difference between the cryoprotectants. B) Lowercase letters indicate a difference between the extenders $(\mathrm{p}<0.05)$. ${ }^{*}$ Statistically less than the fresh sperm $(\mathrm{p}<0.05)$.
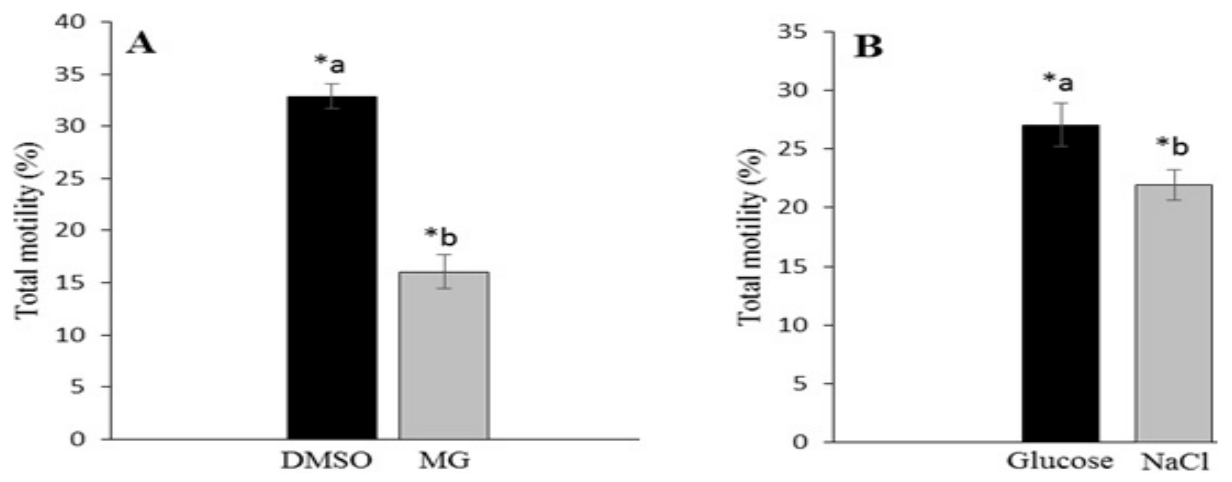

For VCL, the cryoprotectant and extender showed a significant effect (Figure 2A and 2B). DMSO gave better results at $46.53 \pm 0.5 \mu \mathrm{m} \mathrm{s}^{-1}$ when compared to $\mathrm{MG}$ at $43.35 \pm 1.03 \mu \mathrm{m} \mathrm{s}^{-1}$, regardless of the extender and thawing rate used $(\mathrm{p}<0.05)$. Glucose was also better at $46.51 \pm 0.91 \mu \mathrm{m} \mathrm{s}^{-1}$, regardless of the cryoprotectant and thawing rate employed, compared to $\mathrm{NaCl}$ at $43.44 \pm 0.68 \mu \mathrm{m} \mathrm{s}^{-1}(\mathrm{p}<0.05)$.

Figure 2. The mean \pm standard error of VCL, VSL and VAP of cryopreserved sperm of the common curimatã in different freezing media. A, C and D) Lowercase letters indicate a difference between the cryoprotectants within the same parameter. B) Lowercase letters indicate a difference between the extender within the same parameter $(\mathrm{p}<0.05)$. *Statistically less than the fresh sperm $(\mathrm{p}<0.05)$.
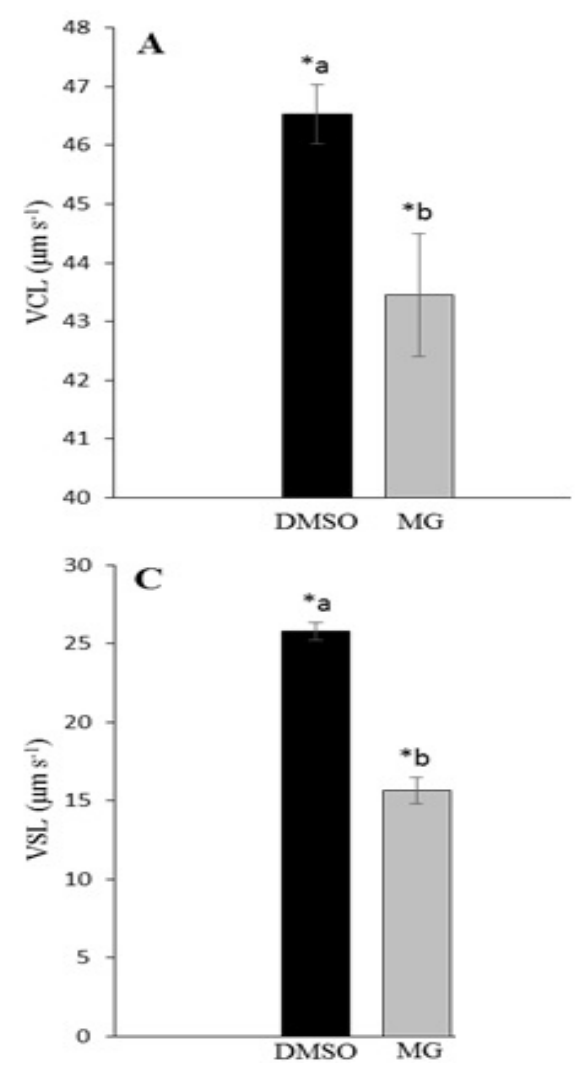
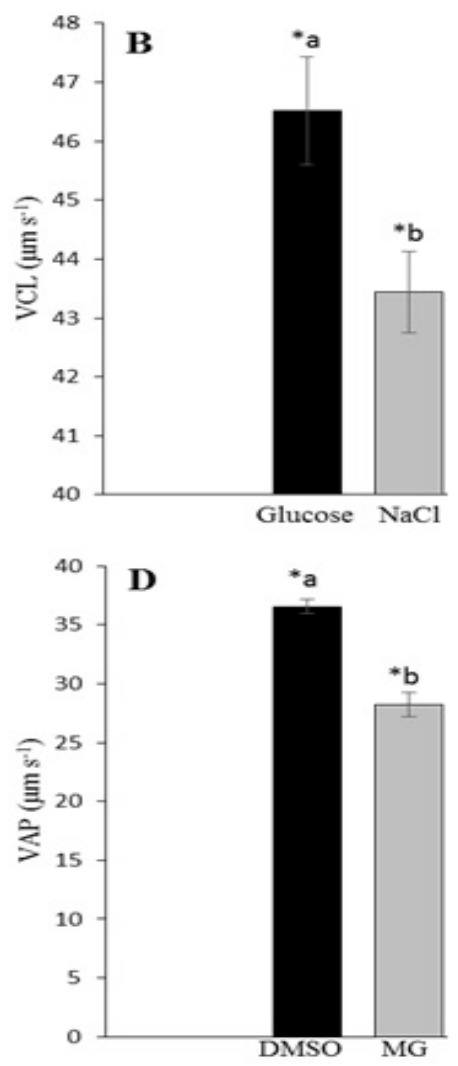
The results of VSL and VAP showed that there was significant effect only on the cryoprotectant (Figure 2C and 2D). Both parameters showed the highest values when the common curimatã sperm was cryopreserved with DMSO, regardless of the extender and thawing rate, at $25.78 \pm 0.56 \mu \mathrm{m} \mathrm{s}^{-1}$ and $36.56 \pm 0.58 \mu \mathrm{m} \mathrm{s}^{-1}$, respectively, when compared to $\mathrm{MG}$ at $15.64 \pm 0.83 \mu \mathrm{m} \mathrm{s}^{-1}$ and $28.23 \pm 1.02 \mu \mathrm{m} \mathrm{s}^{-1}$ $(\mathrm{p}<0.05)$.

Regarding the percentage of live spermatozoa, there was an interaction between the cryoprotectant and the thawing rate (Figure 3). Treatments containing DMSO did not differ between the thawing rate $30{ }^{\circ} \mathrm{C}$ for $16 \sec (56.15 \pm 3.46 \%)$ and $40{ }^{\circ} \mathrm{C}$ for $12 \sec (56.45 \pm 3.26 \%)$, and they were higher than the rate at $25{ }^{\circ} \mathrm{C}$ for $30 \mathrm{sec}(41.61 \pm 3.05 \%)$ $(p<0.05)$. As for the treatments with $\mathrm{MG}$, the best results were found for the semen thawed at $25^{\circ} \mathrm{C}$ for $30 \sec (36.13 \pm 2.79 \%)$ and $30^{\circ} \mathrm{C}$ for $16 \mathrm{sec}(37.01$ $\pm 2.58 \%$ ), which were higher than the rate observed at $40{ }^{\circ} \mathrm{C}$ for $12 \sec (27.60 \pm 2.62 \%)(\mathrm{p}<0.05)$.

Figure 3. The mean \pm standard error of the vitality of thawed semen of the common curimatã. Capital letters indicate a difference in the cryoprotectants between thawing rates. Lowercase letters indicate a difference between the cryoprotectants at the same thawing rate $(\mathrm{p}<0.05)$. D1: thawing at $25^{\circ} \mathrm{C}$ for $30 \mathrm{sec}$; D2: thawing at $30{ }^{\circ} \mathrm{C}$ for $16 \mathrm{sec}$; D3: thawing at $40{ }^{\circ} \mathrm{C}$ for $12 \mathrm{sec}$. *Statistically less than the fresh sperm $(\mathrm{p}<0.05)$.

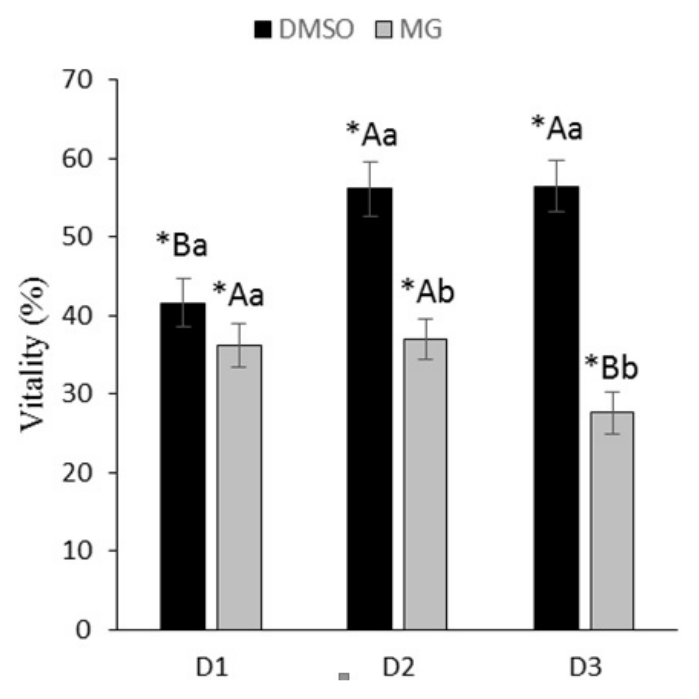

With regard to the morphological analysis, the rate of normal spermatozoa was influenced by the thawing rate (Figure 4). The ratio of normal spermatozoa in the semen thawed at $25{ }^{\circ} \mathrm{C}$ for $30 \mathrm{sec}$ or $40{ }^{\circ} \mathrm{C}$ for $12 \mathrm{sec}$ was similar at $65.71 \pm$ $1.47 \%$ and $65.62 \pm 1.37 \%(\mathrm{p}>0.05)$, respectively, and these results were superior to those obtained with semen thawed at $30{ }^{\circ} \mathrm{C}$ for $16 \sec (60.52 \pm$ $1.79 \% ; \mathrm{p}<0.05)$, regardless of the freezing media. Additionally, for this parameter, there was a cryoprotectant and extender interaction (Figure 5). The sperm cryopreserved with glucose, regardless of the cryoprotectant, showed the best results for normal morphology, with percentages of $67.6 \pm$ $2.01 \%$ (DMSO) and $72.77 \pm 1.32 \%$ (MG) compared with the cryopreserved $\mathrm{NaCl}$, which showed rates of normal spermatozoa of $60.43 \pm 1.21 \%$ (DMSO) and $55.02 \pm 1.55 \%(\mathrm{MG})$.

With respect to the primary pathologies, only the bent tail occurred more frequently in both the fresh sperm $(23.21 \pm 2.56 \%)$ and the cryopreserved sperm. The rate of sperm with this pathology was lower in the semen thawed at $25{ }^{\circ} \mathrm{C}$ for $30 \mathrm{sec}(25.57 \pm 1.16 \%)$, regardless of the freezing media. As a freezing medium, glucose associated with MG promoted lower bent tail indices of $19.78 \pm 0.92 \%$. All other observed pathologies, primary and secondary, showed percentages below $1 \%$ in fresh sperm and did not reach 5\% in the cryopreserved sperm, demonstrating that these types of damage did not significantly compromise the sperm quality after thawing.

In the present study, we sought to characterize the semen prior to cryopreservation, which is the first work to describe sperm velocities (VCL, VSL and VAP) for fresh sperm of the common curimatã. These parameters are important to an understanding of the sperm kinetics of this species and are known to have a direct effect on the fertilizing capacity of the spermatozoa. 
Figure 4. The mean \pm standard error of spermatozoa with normal morphology in the common curimatã sperm when thawed at three different rates. Lowercase letters indicate a difference between the thawing rates $(p<0.05)$. D1: thawing at $25^{\circ} \mathrm{C}$ for $30 \mathrm{sec}$; D2: thawing at $30{ }^{\circ} \mathrm{C}$ for $16 \mathrm{sec}$; D3: thawing at $40^{\circ} \mathrm{C}$ for $12 \mathrm{sec}$. ${ }^{*}$ Statistically less than the fresh sperm $(\mathrm{p}<0.05)$.

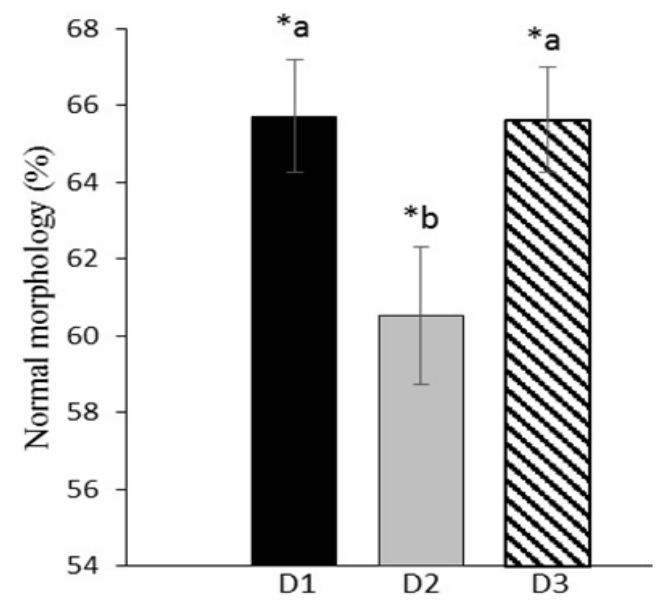

Figure 5. The mean \pm standard error of spermatozoa with normal morphology in common curimatã sperm cryopreserved in different freezing media. Capital letters indicate a difference between extenders. Lowercase letters indicate a difference between the cryoprotectants with the same extender $(\mathrm{p}<0.05)$. *Statistically less than the fresh sperm $(\mathrm{p}<0.05)$.

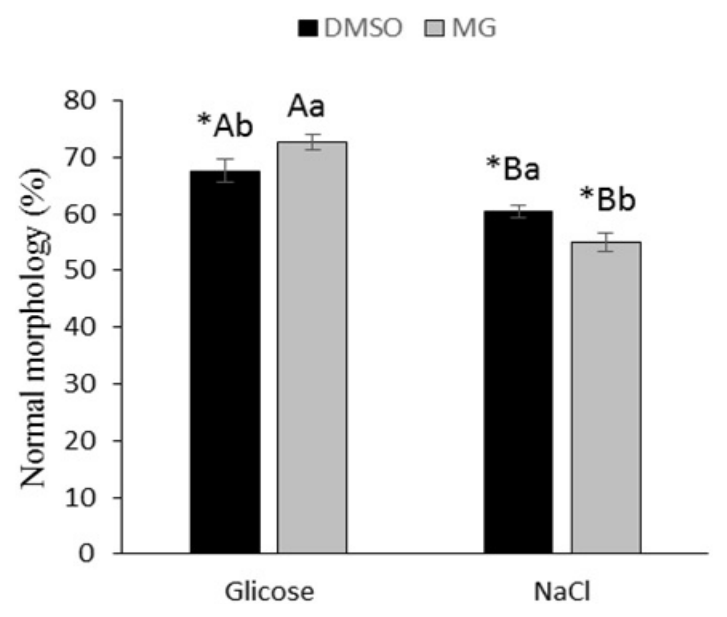

In this work, we observed the importance of studying the interaction between the extender, the cryoprotectant and the thawing rate. This study is one of the first on seminal cryopreservation of $P$. brevis and a pioneer in the evaluation of different thawing rates of semen for that species. The results contribute significantly to improving the development and standardization of a semen preservation protocol for the common curimatã.

With regard to the characteristics of fresh sperm from $P$. brevis, little information is available in the literature, but most published parameters approach those observed in our study. The seminal $\mathrm{pH}$ and osmolarity observed in the present study were similar to those documented in the work of Lopes et al. (2014) ( pH 8.2 and $276.1 \mathrm{mOsm} \mathrm{kg}^{-1}$ ) and Silva et al. (2014) ( $\mathrm{pH} 7.9$ to $\left.287.9 \mathrm{mOsm} \mathrm{kg}^{-1}\right)$, who studied the same species.

The sperm concentration obtained in this study was close to that recorded by Lopes et al. (2014), who reported 22.2 billion spermatozoa $\mathrm{mL}^{-1}$, and was much higher than that found by Silva et al. (2014), who reported 15 million spermatozoa $\mathrm{mL}^{-1}$. The seminal volume observed in this study is lower than that reported by Lopes et al. (2014) but higher than that found by Silva et al. (2014), who recorded $1.31 \mathrm{~mL}$ and $0.15 \mathrm{~mL}$, respectively.

The sperm motility, in fresh sperm, observed by Lopes et al. (2014) was 95.5\%, which was similar to that observed in this work. Regarding the percentage of morphologically normal spermatozoa, the values recorded by Lopes et al. (2014) and Silva et al. (2014) were higher than that obtained in this study, with $97.2 \%$ and $86.7 \%$, respectively.

The variations observed among the results of these works may be related to several factors such as season, climate, sexual rest period, collection method, temperature, nutritional status, health status, analysis conditions and activating solutions, inter alia, as reported by Murgas et al. (2011).

The highest total motility results in this study were obtained using glucose and DMSO (average $33.8 \%$ ) as freezing media, regardless of the thawing rate employed. Lopes et al. (2014) achieved a slightly lower motility using a thawing rate of 25 
${ }^{\circ} \mathrm{C}$ for $30 \mathrm{sec}$ for the same species, with $23.9 \%$ total motility.

In this study, VCL showed a pattern similar to that total motility. According to Morales (1986), the VCL in fish is one of the most relevant parameters, due to the circular motion of the spermatozoa, which facilitates the input of this gamete in the micropyle, allowing the penetration of the gamete into the oocyte before it is closed from hydration. For the other velocities (VSL and VAP), the best results were demonstrated with DMSO, independent of the extender and thawing rate. These parameters, however, also influence the fertilization efficiency (VIVEIROS et al., 2010).

With regard to the percentage of live spermatozoa, higher values were achieved when using DMSO and thawing rates of $30{ }^{\circ} \mathrm{C}$ for $16 \mathrm{sec}$ or $40{ }^{\circ} \mathrm{C}$ for $12 \mathrm{sec}$. This is the first study reporting data on the vitality of $P$. brevis sperm. Martinez et al. (2012) reported higher values of live spermatozoa from frozen sperm of $P$. magdalenae, a species belonging to the same genus of the species under study.

The reduction of temperature during the cryopreservation process leads to the formation of ice crystals in extracellular space. Depending on cooling velocity, ice may form inside the cell, and in most cases cells will become osmotically inactive or lysed due to the loss of membrane integrity (DENVIREDDY et al., 2002). When thawed, spermatozoa undergo the reverse process, which can lead to recrystallization.

The motility and the fertilizing capacity of sperm cells are critical in the analysis of semen quality (BOBE; LABBÉ, 2010); these characteristics are directly influenced by the amount of sperm with intact membranes, showing the importance of the vitality evaluation.

As for the morphological analysis, the highest percentage of normal sperm was obtained using the thaw rates of $25{ }^{\circ} \mathrm{C}$ for $30 \mathrm{sec}$ and $40{ }^{\circ} \mathrm{C}$ for $12 \mathrm{sec}$, regardless of the freezing media; these results are similar to those achieved in the thawing of pacu semen (PAULINO et al., 2012) which was performed at the second thawing rate. In addition, the best result was observed using glucose and $\mathrm{MG}$, corroborating the findings of Lopes et al. (2014).

Among all observed morphopathologies, only the bent tail occurred frequently. Nevertheless, sperm abnormalities, which mostly affect the motility and fertilization rate, include the presence of a tail stump and a strongly coiled tail (CHENOWETH, 2005; MILIORINI et al., 2011), which in this study were irrelevant. Notably, the bent tail morphology is a primary pathology, namely from spermatogenesis.

The maintenance of normal sperm morphology is relevant because the freezing process may cause damage to the morphology, and although sperm motility may be visibly present, the sperm may be unable to penetrate an oocyte. This shows that the degree of abnormality in semen can decisively affect their fertilizing potential (MARQUES, 2001).

Semen analysis using CASA has been reported in other species of fish and has been shown to be a good tool to help determine sperm quality; it provides more information than subjective analysis and more accurate results (NYNCA et al., 2014; VIVEIROS et al., 2014; JUDYCKA et al., 2015; MARIA et al., 2015). This is one of the first studies using CASA in the analysis of fresh and cryopreserved sperm for P. brevis.

The results of this study support the existence of interactions among many factors, ranging from environmental conditions and the handling of the animals to each step of the cryopreservation process, including the extender, cryoprotectant, dilution rate, thawing rate, seminal evaluation methods, etc. (MURGAS et al., 2011;. SALMITO-VANDERLEY et al., 2012.). The process of cryopreservation involves several steps, and some of these have been tested in this work, which has generated relevant information that should be considered in cryopreservation programs of $P$. brevis semen. 


\section{Conclusion}

Although it presents a decline in quality relative to fresh sperm, cryopreserved sperm of $P$. brevis showed promising results. The sperm quality suffered interference from the freezing media, as well as from the interaction between its components (extender and cryoprotectant) and the thawing rate used. Under the conditions of the employed methodology, the cryopreservation of $P$. brevis sperm is best achieved with the use of $5 \%$ glucose as an extender in association with $10 \%$ DMSO as a cryoprotectant, with a thawing of $40{ }^{\circ} \mathrm{C}$ for 12 seconds or $30{ }^{\circ} \mathrm{C}$ for 16 seconds.

\section{Acknowledgements}

This study was supported by the Departamento Nacional de Obras contra as Secas (DNOCS) and Laboratório de Biotecnologia da Reprodução de Peixes (LBRP). We acknowledge the Financiadora de Estudos e Projetos (FINEP) for financial support and the Fundação Cearense de Apoio ao Desenvolvimento Científico e Tecnológico (FUNCAP) for granting the scholarship.

\section{References}

BLOM, E. A one-minute live-dead sperm stain by means of eosin-nigrosin. Fertility and Sterility, Birmingham, v. 1, n. 2, p. 176-177, 1950.

BOBE, J.; C. LABBÉ, C. Egg and sperm quality in fish. General and Comparative Endocrinology, Rennes, v. 165, n. 3, p. 535-548, 2010.

CARNEIRO, P. C. F.; AZEVEDO, H. C.; SANTOS, J. P.; MARIA, A. N. Cryopreservation of tambaqui (Colossoma macropomum) semen: Extenders, cryoprotectants, dilution ratios and freezing methods. CryoLetters, United KingdonLewes, v. 33, n. 5, p. $285-$ 393, 2012.

CHENOWETH, P. J. Genetic sperm defects. Theriogenology, California, v. 64, n. 3, p. 457-468, 2005.

DENVIREDDY, R. V.; SWALUND, D. J.; OLIN, T.; VINCENT, W.; TROEDSON, M. H. T.; BISCHOF, J. C.; ROBERTS, K. P. Cryopreservation of equine sperm: optimal cooling rates in the presence and absence of cryoprotective agents determined used differencial scanning calorimetry. Biology of Reproduction, New York, v. 66, n. 1, p. 222-231, 2002.

DOURADO, O. F. Principais peixes e crustáceos dos açudes controlados pelo DNOCS. Fortaleza: Convênio SUDENE/DNOCS, 1981. 40 p.

JUDYCKA, S.; SZCZEPKOWSKI, M.; CIERESZKO, A.; DIETRICH, G. J. New extender for cryopreservation of Siberian sturgeon (Acipenser baerii) semen. Cryobiology, New York, v. 70, n. 2, p. 184-189, 2015.

LEUNG, L. K. P. Principles of biological criopreservation. In: JAMIESON, B. G. M. (Ed.). Fish evolution and systematics: evidence from spermatozoa. Cambridge: Cambridge University Press, 1991. p. 230-244.

LOPES, J. T.; PINHEIRO, J. P. S.; NUNES, L. T.; PINHEIRO, R. R. R.; SOUZA, M. E. M.; ALMEIDA, P. S.; NASCIMENTO, R. V.; CAMPELlO, C. C.; SALMITO-VANDERLEY, C. S. B. Avaliação de diferentes crioprotetores e taxas de diluição na criopreservação seminal de Prochilodus brevis. Revista Brasileira de Reprodução Animal, Belo Horizonte, v. 38, n. 3, p. 170-175, 2014.

MARIA, A. N.; CARVALHO, A. C.; ARAÚJO, R. V.; SANTOS, J. P.; CARNEIRO, P. C.; AZEVEDO, H. C. Use of cryotubes for the cryopreservation of tambaqui fish sêmen (Colossoma macropomum). Cryobiology, New York, v. 70, n. 2, p. 109-114, 2015.

MARQUES, S. Preservação a curto prazo do sêmen de teleósteos neotropicais de água doce. 2001. Dissertação (Mestrado de Zoologia de Vertebrados) - Pontifícia Universidade Católica de Minas Gerais, Belo Horizonte.

MARTINEZ, J. G.; GARCIA, V. A.; CARRASCO, S. P. DNA fragmentation and membrane damage of bocachico Prochilodus magdalenae (Ostariophysi: Prochilodontidae) sperm following cryopreservation with dimethylsulfoxide and glucose. Neotropical Ichthyology, Porto Alegre, v. 10, n. 3, p. 577-586, 2012.

MILIORINI, A. B.; MURGAS, L. D. S.; ROSA, P. V. A.; OBERLENDER, G.; PEREIRA, G. J. M.; COSTA, D. V. Morphological classification proposal for curimba (Prochilodus lineatus) sperm damages after cryopreservation. Aquaculture Research, Oxford, v. 42, n. 2, p. 177-187, 2011.

MOORE, J. C.; BERLOW, E. L.; COLEMAN, D. C.; RUITER, P. C.; DONG, Q.; HASTINGS, A.; JOHNSON, N. C.; MCCANN, K. S.; MELVILLE, K.; MORIN, P. J.; NADELHOFFER, K.; ROSEMOND, A. D.; POST, D. M.; SABO, J. L.; SCOW, K. M.; VANNI, M. J.; WALL, D. H. Detritus, trophic dynamics and biodiversity. Ecology Letters, Oxford, v. 7, n. 7, p. 584-600, 2004. 
MORALES, J. Aquicultura marina animal. Madrid: Ediciones Mundi-Prensa, 1986. 670 p.

MURGAS, L. D.; FELIZARDO, V. O.; FERREIRA, M. R.; ANDRADE, E. S.; VERAS G. C. Importância da avaliação dos parâmetros reprodutivos em peixes nativos. Revista Brasileira de Reprodução Animal, Belo Horizonte, v. 35, n. 2, p. 186-191, 2011.

NYNCA, J.; DIETRICH, G. J.; DOBOSZ, S.; GRUDNIEWSKA, J.; CIERESZKO, A. Effect of cryopreservation on sperm motility parameters and fertilizing ability of brown trout semen. Aquaculture, London, v. 433, n. x1, p. 62-65, 2014.

PAULINO, M. S.; MURGAS, L. D. S.; FELIZARDO, V. O.; FREITAS, R. T. F. Anormalidades espermáticas de Piaractus mesopotamicus após descongelamento utilizando diferentes metodologias. Arquivo Brasileiro de Medicina Veterinária e Zootecnia, Belo Horizonte, v. 64, n. 6, p. 1591-1596, 2012.

RESENDE, E. K.; MARQUES, D. K. S. Criopreservação de sêmen de peixe. Corumbá: Embrapa Pantanal, 2009. 5 p. (Embrapa Pantanal. Circular Ttécnica, 84).

SALMITO-VANDERLEY, C. S. B.; VIEIRA, M. J. A. F.; LEITE, L. V.; OLIVEIRA, F. C. E.; LINHARES, F. R. A.; SAlGUEIRO, C. C. M.; NUNES, J. F. Meios de congelação para conservação de sêmen de peixes da família Characidae. Ciência Animal, Fortaleza, v. 22, n. 1, p. 255-268, 2012.
SILVA, A. C.; GALVÃO, J. A. S.; TEIXEIRA, E. G.; FARIAS, W. R. L. Caracterização e resfriamento do sêmen de curimatã, Prochilodus brevis (Steindachnner, 1874). Revista Brasileira de Higiene e Sanidade Animal, Fortaleza, v. 8, n. 3, p. 105-129, 2014.

TORRES, T. M.; SOUZA, M. E. M.; NUNES, L. T.; PINHEIRO, B. Q.; LOPES, J. T.; LEITE, L. V.; SALMITO-VANDERLEY, C. S. B. Avaliação de três diferentes corantes na análise da morfologia espermática em sêmen fresco de Curimatã comum (Prochilodus brevis). In: CONGRESSO BRASILEIRO DE REPRODUÇÃO ANIMAL, 2013, Uberlândia. Anais... Uberlândia: EditoraRevista Brasileira de Reprodução Animal, 2013. p. 248.

VIVEIROS, A. T. M.; NASCIMENTO, A. F.; ORFÃO, L. H.; ISAÚ, Z. A. Motility and fertility of the subtropical freshwater fish streaked prochilod (Prochilodus lineatus) sperm cryopreserved in powdered coconut water. Theriogenology, California, v. 74, n. 4, p. 551-556, 2010.

VIVEIROS, A. T. M.; TAFFAREL, T. R.; LEAL, M. C. Osmolality and composition of the extender during the cold storage of Prochilodus lineatus (Characiformes: Prochilodontidae) sperm. Neotropical Ichthyology, Porto Alegre, v. 12, n. 3, p. 643-648, 2014. 
